\title{
Exploring the masculinization of innovation practice within a municipality
}

Caroline Wigren-Kristoferson \\ Lund, Sweden
}

\begin{abstract}
Purpose - The purpose of this study is to generate an empirically informed theoretical framework which can be used to analyze the relationship between gender and innovation in the context of a municipality. The authors present and analyze three illustrative tales from a feminist perspective. The authors thus offer a more balanced approach to the conceptualization of gendered ascriptions with respect to the possible outcomes of innovation work in a public context.

Design/methodology/approach - An ethnographic account which employed "shadowing" as a method of observation.

Findings - The article presents a debate on how the social construction of gender and innovation can be placed in the context of a municipal reality. Our analysis reveals how the complexities of a gendered work life within a municipality can create paradoxes. A constructionism approach was used in the identification of hidden and unspoken paradoxes that exist in public spheres.

Research limitations/implications - The authors used empirical tales from a very specific context, namely a Swedish municipality. The central implication of this study is the recognition of innovation as being masculine-gendered within the feminine context. This implication thereby deepens our understanding of gender paradoxes in the public sector.

Practical implications - This study provides insights to practitioners who intend to work with innovation in a public organization.

Social implications - The social implications of this study is that when a male-gendered concept like innovation is implemented in a female-gendered context, like a municipality, it is of importance to contextualize the concept.

Originality/value - The empirical value of examples of a gendered work landscape at a Swedish municipality.
\end{abstract}

Keywords Gender, Innovation, Municipality, Paradoxes, Reverse tokenism, Constructionism

Paper type Research paper

\section{Introduction}

Traditionally, innovation research has focused on the manufacturing sectors and on product innovations; only lately there has been an increased interest for studying innovation and innovativeness in the private- and public service sectors (Miles, 2005; Mulgan, 2007; Windrum and Koch, 2008). Examples of public innovation research themes are barriers for public innovation, drivers for innovation and conditions for innovation (Bekkers et al., 2013;

(C) Caroline Wigren-Kristoferson and Maria Aggestam. Published by Emerald Publishing Limited. This article is published under the Creative Commons Attribution (CC BY 4.0) licence. Anyone may reproduce, distribute, translate and create derivative works of this article (for both commercial and noncommercial purposes), subject to full attribution to the original publication and authors. The full terms of this licence may be seen at http://creativecommons.org/licences/by/4.0/legalcode
Received 26 November 2020

Revised 9 February 2021 Accepted 20 July 2021 
IJGE

13,3
Demircioglu and Audretsch, 2017). So far, public innovation research has not been very theoretical (De Vries et al., 2016), and research on the relationship between innovation and gender within the public sector is, so far, scarce (cf. Nählinder, 2013). The presence of women has increased in public institutions, especially in the low-value sectors (Marlow et al., 2008), where gender has no role to play in relation, for example, between launching an idea and executing an idea (Foss et al., 2013; Alsos et al., 2013). Other scholars have considered the gender dimension of innovation as merely a peripheral element, and they have thus failed to perceive it as something important (Cooper, 2012; Ranga and Etzkowitz, 2010). Moreover, innovation research in relation to gender has been characterized by "gender blindness" by many scholars (cf. Pecis, 2016; Alsos et al., 2013). The ideology of gender blindness helps to maintain a paradox of silence, in which innovation is embedded. This is a silence in which women tacitly subscribe to a dominant and heteronormative ideology. However, innovation and gender do not exist in a void. Instead, they are created by the influences of specific social structures and norms that are open to scrutiny.

Taking a social constructionism approach to innovation and analyze the gendered innovation practices of a municipal workplace. Furthermore, we interrogate how innovation ascriptions are "talked into being" and then performed through interaction with colleagues. From this perspective, innovation is understood as a socially constructed process, which is embedded within everyday workplace practices.

We argue that socially constructed masculine-gendered innovation ascriptions are produced and reproduced within a municipality and the public sector. Accordingly, our research objective is to explore how the intersecting ascriptions of men and women within the public sector influence innovation experiences as being "gendered.".

The empirical context of the paper is an ethnographic study that was conducted at a municipality. The researcher followed the process of how the municipality made the strategic decision to invest in and work with innovation to move the organization [the municipality] from a focus on improving efficiency to working in radical new ways, with and through innovation. The municipality was much inspired by the Observatory of Public Sector Innovation (OPSI), which is part of the work conducted by The Organisation for Economic Co-operation and Development (OECD). OPSI suggests four facets of public sector innovations, and in the early phase, the municipality focused much on the facet called anticipatory innovations, i.e. to engage with the future and uncertainty regarding what works is appropriate and/or possible. It is about exploring new frames of reference and paradigms regarding how things can work.

Observations from the field reveal that innovation was initially constructed as something radical, scalable and unique. This is interesting as in terms of research, the focus has been on incremental innovations rather than on radical, as radical innovations are rare and unique as they represent fundamental changes and clear departures from today's practices (Abernathy and Utterback, 1978; Ritala and Sainio, 2014). Simply speaking, innovation was addressed in words, concepts and examples that made the concept very exclusive and thereby included only a small group of people. Over time, the concept of innovation was re-constructed. We report on this development by analyzing a few key events and stories from the field. By doing so, we come to reveal innovation as being male-gendered when the concept was introduced to the organization. The value of this study lies in its acknowledgment of the paradox of how innovation in a female-gendered context, like a municipality, is dressed in male-gendered terms. By gaining new insights and knowledge regarding innovation in female-gendered contexts, like a municipality, we contribute to the development of new theoretical insights and to practice.

While the above became evident to us, we examine the ways how a municipality that made a strategic decision to work with innovation took on this challenge. Further, we interrogate 
three tales from the field by addressing gender- and innovation-as-practice, revealing the general understanding that innovation is a masculine phenomenon.

In this paper, we contribute to the debate about the influence of gendered ascriptions on entrepreneurial innovation outcomes. We analyze our illustrative accounts from a feminist viewpoint, examining the asserted association between (1) "gender" and (2) how certain understandings of the concept impact the masculinization of innovation. We also elicited the thoughts and ideas of a number of municipal workers about the promotion of innovation in the female-dominated public sector in Sweden. We thus offer a useful method to analyze the conceptualization of "innovation" in terms of gender since we understand it to be an endogenous process. Innovation is a highly gendered term that creates a barrier to women in the female-dominated public sector. Because there are different understandings assigned to women and men in the innovation process (Duberley and Cohen, 2010), men are inclined to engage in innovation while women are often pushed aside to occupy invisible positions. Through the identification of a paradox, this analysis highlights how the municipality accommodates innovation and how a top-down strategy reveals hidden power relations within the public sphere.

The paper is structured in the following way: We begin with a discussion of the theory we refer to and the research method we employ. Thereafter, the context of the study is presented. We then share with the reader three tales from the field. We end this paper with a final discussion and our conclusions.

\section{Note on theory}

In this article, we employ a feminist perspective as we critically examine prevailing perceptions about innovation as being male-gendered. Feminism is also intimately associated with challenging the normative, gendered order in society. This social order materializes via the reproduction of certain acts and the use of language. We use a post-structuralist feminist lens (Butler, 1990; Irigaray, 1985) to view issues in which female subordination is constructed within and through language. We also refer to Spender's (1985) observations concerning "man-made language" and reveal how language uses symbols and metaphors that persistently represent the feminine as weak and masculinity as strong. This is a useful approach to studying male-gendered innovation within a female-gendered context, a municipality.

From a global perspective, the Nordic welfare state is unique since family policies make it possible for women to work; women's liberation is, to a large extent, a result of the state policy (Ahl et al., 2016). The Nordic counties are known to the world to be gender-equal and genderaware, which contributes to the ideology of gender blindness, maintaining a paradox of silence in which innovation is embedded. However, the Swedish public sector consists of a number of feminine institutions, focusing on caring for children and the elderly, which are characterized by an entrenched gender hierarchy (Acker, 1990, 1992). Women's position in the Scandinavian welfare state is complex; the welfare state implies that women are empowered as employees, mothers and citizens at the same time as there are structures that oppress them (Sum, 1987). Gender is reinforced and frequently expressed through masculine symbols and rhetoric (Acker, 1990, 1992). The gender ideology that exists in Sweden is consistent with an institutional order that silences women and their experiences. This is a circumstance that, in effect, favors men.

In the context of studies on innovation and gender, we know that the concept of "innovation" builds on notions that promote men and certain forms of masculinity as the norm (cf. Blake and Hanson, 2005; Nyberg, 2009). There is a strong association between "masculinity," "science and engineering," "technology" and "innovation" (Wajcman, 2010; Marlow and McAdam, 2012). The lack of gender perspectives in these domains has been, for

Innovation practice 
IJGE

13,3

246

example, previously explained in terms of the small number of people who are engaged in innovation studies: when people are left out, gender is left out (Alsos et al., 2013). One way to include people in innovation studies is to focus on practice. This includes a change in the field of innovation studies, fields that have turned to the practice turn are, for example, the field of entrepreneurship (Thompson et al., 2020) and strategic management with the development of the strategy-as-practice domain (Seidl and Whittington, 2014; Whittington, 1996). To further develop the field of gender studies in relation to innovation, we need to acknowledge practice.

Studying what takes place at a municipality is of interest since doing so can contribute to our knowledge about innovation in a female-gendered context. Note that in the municipality that was studied, almost $80 \%$ of the employees are female. Public sector innovation is a relatively new area of research, and consequently, there still remains a lack of in-depth qualitative studies that investigate why and how innovations can be embedded into a public context (Djellal et al., 2013). Most existing research on public sector innovation is on intraorganizational administrative processes (often technology-driven), which relate to either NPM (New Public Management) or e-government (De Vries et al., 2016). Thus far, however, public innovation research has not been very theoretical in its approach (De Vries et al., 2016). By using a gender perspective, we contribute to the theory relevant to investigating the field of public innovation.

\section{Note on method}

Three tales constructed from the two-year ethnographic study of the municipality constitute the empirical material used in this study. Notes from participant observations and narrative interviews were analyzed to delineate how innovation work is gendered.

From October, 2018 to October, 2020, one of the authors was an embedded researcher in the municipality in question. Being embedded implies that one "investigate from within the subject of study" (Morgan and Smircich, 1980, p. 498). The study was conducted within an interpretative paradigm of inquiry since we claim that " $t$ the qualitative researcher is not an objective, authoritative, politically neutral observer standing outside and above the text" (Lincoln and Denzin, 2000, p. 1,049). The opportunity to live and to learn the everyday worklife processes within an organization enables the researcher to learn about the different meanings that construct the everyday lives of the people who work there, including "the routine, daily lives of people" (Fetterman, 1998b, p. 473). In the context of studying "everyday life" at the municipality, being embedded allowed the researcher to develop understandings that would not be possible to obtain through mere snapshot visits or through interviews. Spending two years at the municipality implied for the researcher a movement from being an outsider to becoming, almost, an insider. An emic understanding (Fetterman, 1998a) about the organization was created by the researcher and enabled the researcher to engage with multiple perspectives and interpretations. Rosen (1991, p. 16) (based on Nelson, 1969) writes: "only by 'direct participation' in the affairs of a social group can the ethnographer come to understand the actions and meanings of those who constitute the group." The researcher's direct participation contributed to developing a deep understanding of municipality life.

In the field, the researcher took notes of what took place at meetings, workshops and other activities. The technique of shadowing was applied (Czarniawska, 2007). The researcher also conducted many narrative interviews during this time. The municipality employs almost 10,000 people, and close to 150,000 inhabitants live in the municipality. The researcher was embedded in the strategic department of the city management administration. Employees were interviewed based on their role in the organization.

Spending two years in the field implies that the researcher was able to cultivate a number of friendships and acquaintanceships with many of the employees, a crucial aspect of the nature of the study. A notebook, a tape recorder and a mobile phone with a good camera were 
the tools that were used in the everyday work-life of the researcher. Fetterman (1998b) claims that a good ethnographer is both a good storyteller and a good scientist. If the researcher is able to get close to "the natives" and to the studied phenomenon and can convey these experiences in a text, then good ethnography and good science are performed.

This study builds on the assumption that reality is enacted, and research is constructed, i.e. the study adopts a social constructionist approach (Rosen, 1991, p. 6). The tales in this text are written in a "confessional” style (Van Maanen, 1988). The researcher's own experiences and reactions inform the text, giving the reader an understanding of how the researcher came to know the research field. In this approach, barriers are acknowledged, the fieldwork process is unmasked (Van Maanen, 1988), and subjectivity is no longer placed on a hidden agenda or in any way suppressed. The confessional style demands that the researcher employs an honest way of writing since all of the relevant information is filtered through the researcher. During the ethnographic process, people are not ascribed certain interpretations; instead, an understanding is constructed in the interaction process by the person who conducts the research and the people who are being researched. Writing ethnography is a fundamentally interpretive act since the researcher interprets when he or she talks with people and is the spectator when reading a text. Interpretations are recorded in the form of field notes and returned to in later phases of the research process, which implies that a text is always a construction.

Regarding how to write within the ethnographic tradition, Richardson (1995, p. 218) provides the following advice:

If we wish to understand the deepest and most universal of human experiences, if we wish our work to be faithful to the lived experiences of people, if we wish for a union between poetics and science, or if we wish to use our privileges and skills to empower the people we study, then we should value the narrative.

Three tales that are constructed based on empirics from the field constitute this study. These three tales are included here because they represent the innovation work in the organization from different organizational levels: (1) the top management, (2) the accelerator in the organization (the innovation department), and (3) an innovation project. All three tales can be seen as symbols for the innovation work in the municipality, and they are all visible in the organization. There are, of course, much more processes and work taking place in the organization, but in this specific article, we focus on three tales that can be considered as espoused tales.

The first tale represents how top management in the organization argued for a focus on innovation. During the researcher's two years in the organization, several events took place where the top managers presented arguments for why the organization should work with innovation and also that innovation is the responsibility of all employees. The events were organized for the employees and, on occasion, to external stakeholders, too. During these events, a few arguments and statements were repeatedly referred to. The arguments that were presented by the top management were of importance to the organization because they were arguments concerning the setting of goals and expectations for the employees.

The second tale that we report on in this study is the inauguration of the municipal organization's accelerator. The accelerator is an organization and physical meeting place in the municipal organization that is supposed to support different departments within the municipality in their innovation work. The accelerator also possessed a symbolic role in the organization since its mere existence announced to the rest of the municipality that innovation work is important work and is highly prioritized in the organization. Finally, the third tale that we share here is about a specific innovation project. This innovation project has received much attention in the organization.

Innovation practice 
IJGE

13,3

248

\section{The municipality in focus}

Three years ago, a group of representatives from the municipality and a number of external actors engaged in a process that resulted in a structural reform in how the municipality would work with innovation in the future. Included in this reform was the creation of a physical place within the organization that would be dedicated to innovation. This decision resulted in the founding of the municipality's accelerator. A political decision was also made to invest money into this project. The necessary funding was secured by the municipality by making an ownership withdrawal from one of the municipality's companies. This money ( $€ 23 \mathrm{~m})$ was then invested in innovation work. It was agreed that part of the money would be used for initiating, testing, and implementing innovation projects within the municipality and part of the money would be used for a city expo in 2022 . At the expo, the innovation work will be presented to inhabitants and external actors. In this context, an additional political goal was decided on; namely, the municipality should become one of the most innovative cities in Europe before 2022. This status should be acquired by competing in The European Capital of Innovation (iCapital), organized by the European Union. The municipality participated in the competition in 2020 and they placed quite high.

By using the above-mentioned three tales from the field, we analyze how this strategy was implemented by the organization. The first tale exemplifies how the top (male) managers in the municipality communicated the municipality's need for innovation. This account informs us, of course, that the innovation strategy was a top-down project, but it was the municipality's employees who were tasked with its implementation. The second account we share here concerns the inauguration of the accelerator in the municipality. This tale shows how "innovation" was equated with technological product innovations, even though process innovations remain relevant to welfare services. The third tale exemplifies a specific innovation project at the municipality. This final tale shows us how a robot for pre-school children became a symbol of innovation in the municipality.

\section{Working with innovation - a top down initiative}

Arguments for why the municipality should work with innovation were presented at a number of internal and external events. One argument put forward is based on the demographic changes present in the municipality. It had been observed how the population of young people and old people was growing, while the population of people who were gainfully employed and paid taxes was becoming smaller. At an internal municipal event, the Municipal Chief Executive [MCE] [1], explained why the municipality should work with innovation. He explained the need for innovation from the perspective of improving economic growth in the municipality. After presenting the demographic changes mentioned above, he reported the following:

So, this puts a lot of pressure on our economy, while at the same time the expectations that our residents have are increasing. They want better service, more service, faster service. And we also have quite large societal challenges, (. . .) that is, climate challenges, security. (. . .) So, we have a really tough condition ahead of us, and the municipal assembly are now discussing how we should solve this. (. . .) they said this: We want to try to find new solutions on how to solve our mission. (...) we are now investing 23 million Euro over the next three years to help the organization find these new solutions, both to ensure welfare, ensure the quality of schooling, care, and nursing. But, also to find solutions to build a smart, sustainable city. The municipal assembly say that they want to take a step forward and show Sweden and the world how to build a smart and sustainable city (.. . I I know that a lot is happening in the organization now, in your organization, to really be able to respond to this. (. . . ) take a step forward, we will really solve it. Do you agree with that?

The words "we will really solve it" refers to the role of the civil servants, who are supposed to do this in practice and innovate to develop solutions to the municipality's problems, in 
cooperation with others, for example, the inhabitants of the municipality, civil society, companies and universities, and internally, between the various municipal departments. Acting was deemed to be of great importance. Additionally, MCE stressed that everybody should learn more about artificial intelligence because he claimed this technology will radically change society and the way the municipality works.

The main task of a municipality is to deliver welfare services, e.g. schooling, elderly and handicapped care, and nursing. Those tasks are performed by women, but only briefly mentioned. Emphasis is put on becoming a smart and sustainable city. A city would use different types of electronic methods and sensors to collect data, which can be used in the city's pursuit of becoming more efficient and improving municipal services.

In the municipality, the hierarchies are obvious. The municipal assembly has the power to make strategic decisions since it is democratically elected by people. The job of the MCE is to fulfill the will of the municipal councilor. In this specific municipality, both are men.

We should note that the municipal employees were tasked with the successful implementation of the MCE's innovation strategy. In this municipality (as in all municipalities across Sweden), the great majority of the employees work with welfare services. Consequently, they have little or no time to assign to working with innovation. Their days are filled with face-to-face interactions as they work to secure high quality of services, as expected by the municipality's residents and by its management team. Given the above circumstances, one might come to the conclusion that innovation work is for those civil servants who have the authority to decide over their own time at work.

Another regular internal event was the municipality's employee day, which was a huge event where almost 10,000 of the municipality's employees were expected to attend. Because the great majority of the employees work with delivering welfare services, like schooling and care, a number of these activities had to close for this occasion. For the employee day, a large hall was festively decorated. The topic of the employee day was "innovation." The chairman of the municipal board, together with a representative for the opposition party, was on stage to welcome the employees and to introduce the topic. The chairman of the municipal board referred to the coming three years and said:

So now, during these three years, together, we will try to present new smart solutions, new ways of working, new ways of meeting the societal problems that all municipalities face.

The representative from the opposition party added:

I think we should stop thinking about changes, innovations, and improvements as if it is someone else's responsibility. There is no one else, but we must see it as a task in our everyday lives, and that I, you, and all of us here in the city should ask ourselves "What can we due to make X a better place?"

Later, while sitting with a group of colleagues who worked with elderly care, we spoke about their lack of resources. The researcher's concern, namely that innovation work is the responsibility of only a few people, was confirmed. In every organization, there exists an inherent sense of-equality regarding the type of position different people hold.

Part of the employee day included a presentation of employees who had made outstanding achievements in their work for the municipality. These achievements were exhibited in a large room. In another room, a female entrepreneur gave a lecture on innovation and the techniques one can use to generate new ideas. A small box of candy was handed out to each participant with the text: You are an enabler. The idea that all employees should perceive themselves as enablers (with respect to innovation) was a key message communicated across the municipality.

In summary, for this municipality, innovation is viewed as a strategic tool that can be used to transform the organization so that it will be better able to face future challenges. Innovation is also perceived to be a tool that the municipality can use to win international recognition. 
IJGE

13,3

What is more problematic, however, is that only a limited number of employees at the municipality have the authority to act outside their prescribed job descriptions, given that they are employed to deliver welfare services. This is the case even though the message broadcasted in the above quotes was that innovation is the responsibility of all the employees. The sub-text that was present at this event was that no one in the organization should hinder innovation and change, and every employee is expected to embark on this journey with an open mind.

The quotes above illustrate that individuals with power created an innovation narrative aimed at both impressing and seducing the municipal employees. From a feminist perspective, (and perhaps from just a common sense perspective, too), this way of speaking can be defined as patronizing. The department for healthcare employs nearly $30 \%$ of all the municipality's employees, and the department of School and Leisure and Recreation Services employs nearly half of the employees in the organization. This entails that $80 \%$ of municipal employees are in a role where they deliver welfare services. These employees, however, lack one important resource: namely, time. Since they are employed to deliver welfare services, this implies that these workers enjoy very little "slack time" at their workplace. Notwithstanding this, they were still encouraged to take action and be innovative. However, when such a challenge is to be met, it is important that the management team consider the context of the organization and the situation of its employees. An important question to ask here is What resources do the employees have access to to fulfil the expectations that the top management has placed on them? If the prerequisites for fulfilling a task are not properly considered, then there is a risk that certain people will feel patronized. This is especially true when the message is delivered by a group of men to a group of subordinated women. Note that at the Department of School and Leisure and Recreation Services, 23\% of the employees are men, and $77 \%$ are women. At the department of Healthcare, the corresponding employment figures are $13 \%$ men, and $87 \%$ women.

Innovation is an example of a "magic concept" (Pollitt and Hupe, 2011). A concept that is difficult to define because it is very broad, and it tends to be normatively charged, in the sense that it only has positive connotations. It is no easy task to find a distinct opposite to a magic concept. For example, we may ask What is the opposite of innovation? Which organizations do not want to be modern and progressive? If we consider innovation as a magic concept, perhaps its magic can explain why two politicians who represent two different ideologies could share the same stage and share the same message. However, neither of the politicians really articulated a clear definition of the concept of innovation, leaving the employees oblivious to the real nature of the task they had been assigned to perform.

\section{The inauguration of the accelerator}

The municipality inaugurated its innovation accelerator a little more than a year ago. It is placed in the municipality's organizational chart under the digitalization department. It is located in modern office space in the city center and occupies two floors, and a large staircase. When one enters this office space, one will immediately make association with an IT company and not with a public service establishment.

The employees who work at the accelerator have different competences and skills. Some work as coaches, some work with service designs and some are programmers. The managers at the accelerator fall under the work title: "innovation strategist." The group employed at the accelerator consists of 29 people: nine women and 20 men. The largest group within the accelerator is the group of programmers, which consists of 11 men. The primary focus of the work done in the accelerator is on digitalization.

The accelerator is a place where employees can learn different methods and approaches to entrepreneurship and innovation. Currently, the accelerator supports the different 
departments in their very early phases. At a later phase of their development, it is the responsibility of each department to embed innovation into its everyday work.

At the inauguration of the accelerator, visitors were guided through the accelerator and were presented with a range of different innovations at different stations. During this event, visitors were expected to stay at each station for about 10 minutes and then move on. The idea behind this continual movement of visitors was to stage an experience of a physical place where things were "happening" and where energy was abundant.

Seven different stations were set up, each one presenting innovations. The majority of the stations displayed different product innovations that had been developed by the municipality; for example, a prototype of a robot that had been developed for pre-school children, Chatbots, how virtual reality can be used to recognize faces and examples of how the Internet of Things [IoT] can be used. The people who attended the inauguration event were provided with the opportunity to see several product innovations that the municipality had, thus far, worked on.

The innovations that were presented at the inauguration were mainly product innovations and related to digitalization. In fact, these innovations could have been developed by private companies, and some of the examples were developed in collaboration with external actors. It is interesting to note that while a private company may focus on products/services for the private market, a municipality, on the other hand, by its very nature should focus on products/services that provide value and benefit to the municipality's inhabitants. Keeping the inhabitants' needs and benefits in focus is crucial. While innovation itself can be the goal of a private company, innovation in a politically controlled public organization must always be a means and never an end.

From previous research, we know that innovation is strongly linked to the private sector and is associated with ideas that are technological and product-driven (Blake and Hanson, 2005). Furthermore, as noted above, it is a male-gendered concept (Amble, 2010; Kvidal and Ljunggren, 2010; Ljunggren et al., 2010; Nyberg, 2009). This is also how the visitors to the inauguration of the accelerator were introduced to innovation. The examples that were showcased at the event were all product innovations with a prominent technology component. Note that services and processes are central to the provision of welfare services.

\section{A robot for preschool children}

Early in the process, each department in the municipality was invited to the accelerator to participate in a creative process. The group of employees who attended the accelerator was asked to identify a challenge that they wanted to work with. The Department of School and Leisure and Recreation Services participated in this type of activity.

The process started with collecting ideas from employees and students from several different schools. The ideas were grouped into different themes. This process was assisted by the accelerator and was considered to constitute a bank of possible challenges the department was facing. During the subsequent workshop, the participants decided to work on one theme. Three ideas were further developed: (1) an idea about checking attendance in a better way; (2) an idea regarding how teachers and students could share knowledge with each other in a more equitable way, where each party could be seen as a resource and (3) a robot for preschool children. When the groups working with the ideas had presented their ideas, the head of the administration for the department decided on which idea to continue working with.

In this specific case, the idea chosen involved the development of a robot for preschool children. The idea came from a male educator who worked at a preschool. In his role as an educator, he had worked quite extensively with computer programming and introduced this field to the children he taught. We thus note that technology was, and is, something that he is passionate about.

Innovation practice 
IJGE

13,3

His idea was to develop a robot that could answer the common questions that preschool children ask. This included questions like who will pick me up today? Which clothes should I wear when I go out to the playground? What will we be served for lunch? These are questions that this educator reported were being asked several times per day. AI is used to generate the answers to these questions.

A so-called "sprint" was organized to develop the idea further. A prototype was produced, and several children were also invited to the accelerator to participate in the development process. The prototype was later tested at a preschool and evaluated.

The entrepreneur, the male educator who initially came up with the idea, received the opportunity to work on the idea since resources were assigned to him from the municipality. Almost two years after its inception, the robot has been tested in 18 preschools and remains under development. Physically, the robot is on an iPad, and the answers it provides are generated through artificial intelligence. The municipality sees it as a strength that the children who use the device can find their answers by themselves. The municipality has also acknowledged that the robot is much appreciated by educators, children and parents because the information that it provides is "correct" and presented in a standard form to everyone.

This innovative idea can be discussed from many different perspectives. However, in this specific context, it is of importance that we note a few things. First, it is male employees who received resources to develop an idea, even if $77 \%$ of the employees are women. Second, technology is replacing human interactions. Third, it is an innovation base on technology and $\mathrm{AI}$, answering the call from the MCE (see the first tale above).

\section{Paradoxes in gender, innovation and the municipal context}

A constructionism perspective is exceptionally useful for the investigation of public organizations, primarily because it requires subjectivity and reflexivity. A feminist point of view is also of use when the researcher wishes to interpret things hidden between the lines. The first tale revealed how expectations were pushed onto the women working at the municipality without providing them with adequate resources to fulfill these expectations. The second tale revealed how innovation is adapted as a male-gendered concept by promoting and focusing on technological product innovations. The third tale indicated to us that innovation resources are readily made available for the development of technological product innovation. Furthermore, we note that the intrapreneur who is responsible for developing the technological product innovation and who was given resources from the municipality is a man. The perseverance of gender inequality supports our claim that women's interests, which often lack the legitimacy of authority, thus appear as a paradox.

Another paradox lies between the image that the country projects abroad with respect to gender equality and the reality of gender equality at the municipal level. There is an obvious unspoken and hidden conflict between the government's and other public authorities' policies regarding gender equality and the highly gendered reality that exists in Sweden's workplaces.

Sweden is known internationally for its gender equality and is often described as an example of "state feminism" (Stetson and Mazur, 1995). According to Hernes (1987, p. 11), the term state feminism refers to "feminism from above" in the sense that public policies promote gender equality. This paradox refers to what Ahl (2006, p. 613) has called the "gendering of institutional order" and is indicative of an asymmetrical gender system and the presence of gendered systems of inequality. This gender inequality may be explained (and sometimes legitimized) as an inevitable after-effect of policy distinctions (Martin, 1990, p. 344).

Sweden is a nation that is profoundly divided, both economically and politically, into regional blocks, or economic zones, where we find certain municipalities which are currently competing against each other to find out which one can show the best entrepreneurial spirit. 
How can a municipality revive a spirit of entrepreneurship and ambition in a region? In the case study under investigation, one solution is innovation. This presents another paradox because, traditionally, Swedish municipalities have constituted a non-innovative sector (Nählinder, 2013).

The standard conception of employment at a municipality presents yet another paradox. The collective ideas concerning municipal employment have triggered novel ideas within the municipality, which, in turn, apply to masculine-gendered outcome innovation tasks. The identification of masculine-gendered attitudes enacted as novel innovation causes disproportionate effects on the process outcome. These masculine attitudes may also secretly add glamor to the innovation in the sense that it is perceived as a task that possesses the allure of progress. It is reasonable to think that the male-constructed strategies that exist within the municipality reflect the municipality's ambivalence regarding the extent to which female employees may benefit from their employment at the municipality. In this respect, work-related segregation has been revealed to be key to supporting hidden discrimination against women. By emphasizing the role of radical innovations and not incremental and stepwise innovations, a large group of employees felt excluded from the process. A lesson that can be learned is to carefully consider how a concept like innovation is introduced into an organizational context. Depending on how the organization introduces the concept, they can either open for an inclusive process or a process that strengthens existing structures and becomes exclusive.

This implies that municipal entrepreneurship can be identified at two levels. At the institutional level of the municipality (in Sweden), it is a radically new idea to set up an internal accelerator. Deciding to implement an accelerator at the municipality can be seen as a strategy formulated by the "ruling class," i.e. at the top management level. Notwithstanding this, an accelerator where people fail to take action is quite useless: the action taken by the different municipal departments will result in public innovations. The employees, however, employ certain tactics and decide on what they want to do. In this process, the head of each department plays a significant role. However, note that it might not be the head of the department who actually takes the necessary innovative action. Ideas are, most frequently, initiated by individual employees, and note that these individuals' ideas often challenge established ideas and routines at the municipality. We thus find municipal entrepreneurs at different levels within the municipality, but who benefits from this? The hidden ideology of the male-gendered authorities at the municipality reveals this evident paradox.

While it is not the case that all innovation strategies can be identified as entrepreneurship, in the context of the present study, we argue that the municipality is engaged in an entrepreneurial act when it sets the goal that the city should become one of Europe's most innovative cities within the near future. But again, we may well ask who is setting the goal?

"Tokenism" is a theoretical construction (Kanter, 1977) evidenced by unequal gender positions at a workplace. Unfortunately, it has not lost its appeal in current gendered situations at the workplace. Tokenism remains a discriminatory practice and could easily be observed in the municipality's work practices. We find it useful to illustrate current manifestations of tokenism in terms of the paradoxes that it engenders, which we provide support for by the three presented tales.

We argue that, with respect to both gender-related paradoxes and paradoxes that can be related to tokenism, this type of analysis is suited to developing an understanding of the complexity of gendered processes within a hetero-normative societal landscape (a landscape that silently demands conformity and subordination).

In classical terms, tokenism (Kanter, 1977; Martin and Collinson, 2002) refers to situations where certain subgroups of workers sometimes find themselves in the minority. These groups primarily consist of women who are ill-treated by their work lives. However, the same women may be used as tokens by the organization when it presents its work on gender. In the
Innovation practice

253


IJGE

13,3

context of the present study, we reverse the concept and discuss it in terms of reverse tokenism to reveal a paradox. Most municipal employees are women, but they are pressured into assimilating strategies of innovation that have been created by a male minority. Because innovation, as a concept, is male-gendered, we should reflect on and contextualize the concept in terms of its role at the municipality in question. This was not done by the municipality itself, thereby resulting in a situation where the concept was adopted as male-gendered, which rendered the concept exclusive and excluding in practice. Our analyses highlight the gender paradoxes implicit in the tales shared with us, and we show how putatively benevolent municipal practices can reveal power relationships since they failed to reflect upon the gender issues inherent to the concept of innovation. When innovation was discussed, masculine metaphors were used, for example, as is apparent in words lean, efficient and competitive. Female metaphors, for example, those invoked by words such as empathetic, supportive, kind or caring were not used in the context of innovation at the municipality. If the concept had been reflected on and contextualized at the municipality, then the innovation practice may have been different in its nature.

To summarize, women have been empowered within Swedish public policies but in practice subordinated by male domination. The paradox of reverse tokenism exemplifies this and points to the fact that women are also neglected in the female-dominated municipal sector. This implies that even if the ambition is to be gender equal paternalistic societal structures that promote reverse tokenism are reinforced. Reverse tokenism is deeply rooted, and it fundamentally disadvantages women.

\section{Conclusion}

As noted at the beginning of our paper, innovation is a socially embedded activity, an activity available to and pursued by individuals who are shaped by the socially constructed institutional contexts they encounter. We adopted the view that masculine innovation practice is socially and normatively situated and organized according to common gender practices. As per our analysis, $80 \%$ of the workforce at the municipality is female. Notwithstanding this majority position, they are disadvantaged by and through gendered ascriptions and responsibilities, a circumstance that fuels a condition of segregated and associated subordination to the masculine norm regarding innovation. This circumstance we find to be a paradox, which informs us that the women at the municipality are viewed as "deficient men."

Our study shows that the context from which innovation may emerge plays a significant role. We thus claim that the municipality culture is of great importance for understanding innovation in a public services context. Existing municipal practices for understanding what innovation entails are still in development. It is apparent that, in the public sector, most employees are women who possess a high degree of potential with respect to innovation, but they find themselves working under a prevailing masculinized culture and under the rule of men, which, in turn, suggests the existence of another practice-paradox. Our analysis also reveals that local departments in the municipality have important roles to play. It is of utmost importance that innovation is gender-equalized and is accepted as part of everyday life at the micro-level at the municipality. The effects of the masculinized gender culture of innovation are associated with the reproduction of well-rehearsed male-cultural practices, which give rise to negative consequences in society. Our analysis shows how the social and political goals of gender equality that are built on egalitarian values become paradoxical and inadvertently reproduce power relations and the contradictions that we found between men and women.

There is a risk that we adopt a hegemonic perspective on why a municipality should work with innovation and how innovation is developed (Boje et al., 1999, p. 341). Clegg (1989, p. 160) 
defines hegemony in terms of the degree it (1989, p. 160) "involves the successful mobilization and reproduction of the active consent of dominated groups." In such circumstances, there is a risk that the hegemonic force "of one social class, gender or culture over another, can be an invisible prison of intersecting gazes to those who have little power to negotiate or even voice alternate stories defining and shaping their existence" (Boje et al., 1999, p. 341). People with less power remain silent.

By analyzing the contradictions and paradoxes associated with the implementation of innovation at the municipality, we can engage in a more complex debate in the field of gendered innovation and gender studies. Our paper clearly illuminated the presence of an asymmetrical gender understanding in the practice of innovation. It, furthermore, explored the intricacies of the deep inequalities that inform the provision of welfare and other services. Understanding an inherently female practice requires that one engages in critical reflection on the discriminating socio-cultural forces that dominate the public sector. The research community is often reluctant to break the taboos of mainstream thinking. If we do not debate, discuss and act on these issues, then our silence on these matters underestimates the gender inequality that is currently in hiding in male-dominated organizations, thereby leaving it free to reappear in more elusive and pernicious forms, which masculinized innovation is but one example.

\section{The voice of the embedded researcher, an epilogue}

My time in the field had come to an end, and I was to have my so-called "exit conversation" with the group of researchers who were to evaluate my project. Part of the conversation included both my manager at the municipality and my manager at my academic institution. My manager at the municipality summarized what I had done and how I had contributed to their work. He explained that, when I first came to the organization, they had just embarked on a journey to work with innovation. They were expected to transform their organization and make innovation part of their daily work, to ensure the provision of good welfare services in the future. He explained that doing innovation work is often an exclusive process, in which only a few people are involved. At the municipality, they talked about the global impact of their innovations, radical innovations and scalability. He said that, when I gave a public presentation of my work in the organization, something changed in the organization. He told me that my presentation had made them see and discuss innovation in a new way. Apparently, I had contributed to the democratization of innovation, and consequently, innovation became much more inclusive, he said. This article thus frames the time spent in the field, in the theoretical context of gender and innovation.

\section{Acknowledgments}

The authors are grateful for comments received from the two anonymous referees and to Riksbankens Jubileumsfond, who has funded the research.

It was a honor to be asked to write this text for the 2021 Legacy Special Issue of the International Journal of Gender and Entrepreneurship. I was nominated by two senior colleagues, thank you for the nomination and thank you, Professor Colette Henry, for considering the nomination. All three are highly appreciated role models in my academic life, you contribute with insightful work on the important topics of gender, innovation and entrepreneurship. You make a difference in this field. Finally, thank you to my co-author, another role model. We met a decade ago in academia and from the get-go, we realized that we shared quite similar frames of reference regarding our academic perspectives and interests. At that time, Maria was preparing to leave academia. She did leave physically, but not

Innovation practice 
IJGE

13,3

intellectually. We embarked on a journey together, researching gender and entrepreneurship. I am pleased that we could co-author this text together, too. This short note is a humble acknowledgment of four women, all sharing a genuine interest for gender studies. Furthermore, as senior researchers, they care for and uplift younger scholars.

Funding: This study is funded by the Flexit Project of the Swedish Riksbankens Jubileumsfond: RMP18-0988:1.

\section{6}

\section{Note}

1. The internal event was the release of the annual report that presents the main challenges for the municipality. The report is based on a statistical analysis of the municipality's operations and trends in society. This event took place in the Spring of 2019.

\section{References}

Abernathy, W.J. and Utterback, J.M. (1978), "Patterns of industrial innovation”, Technology Review, Vol. 80 No. 7 , pp. 40-47.

Acker, J. (1990), "Hierarchies, jobs, bodies: a theory of gendered organizations", Gender and Society, Vol. 4 No. 2, pp. 139-158.

Acker, J. (1992), "Två diskurser om reformer och kvinnor i den framtida välfärdsstaten”, in Acker, J., Baude, A. and Björneberg, U. (Eds), Kvinnors Och Mäns Liv Och Arbete, SNS Förlag, Stockholm, pp. 280-312.

Ahl, H. (2006), "Why research on women entrepreneurs needs new directions", Entrepreneurship: Theory and Practice, Vol. 30 No. 5, pp. 595-621.

Ahl, H., Berglund, K., Pettersson, K. and Tillmar, M. (2016), "From feminism to FemInc.ism: on the uneasy relationship between feminism, entrepreneurship and the Nordic welfare state", International Entrepreneurship and Management Journal, Vol. 12, pp. 369-392.

Alsos, G., Ljunggren, E. and Hytti, U. (2013), "Gender and innovation: state of the art and research agenda”, International Journal of Gender and Entrepreneurship, Vol. 5 No. 3, pp. 236-256.

Amble, N. (2010), "Regional innovation and the 'catch' of women", Paper Presented at the Conference Gender Work and Organization, Keele University, Keele, 21-23 June, 2010.

Bekkers, V.J.J.M., Tummers, L.G. and Voorberg, W.H. (2013), From Public Innovation to Social Innovation in the Public Sector: A Literature Review of Relevant Drivers and Barriers, Erasmus University, Rotterdam.

Blake, M.K. and Hanson, S. (2005), "Rethinking innovation: context and gender", Environment and Planning A, Vol. 37 No. 4, pp. 681-701.

Boje, D., Luhman, J. and Baack, D. (1999), "Hegemonic stories and encounters between storytelling organizations", Journal of Management Inquiry, Vol. 8 No. 4, pp. 340-360.

Butler, J. (1990), "Gender trouble, feminist theory, and psychoanalytic discourse”, in Nicholson, L.J. (Ed.), Feminism/Postmodernism, Routledge, New York, pp. 324-340.

Clegg, S.R. (1989), Frameworks of Power, Sage, London.

Cooper, R. (2012), "The gender gap in union leadership in Australia: a qualitative study", Journal of Industrial Relations, Vol. 54 No. 2, pp. 131-146.

Czarniawska, B. (2007), Shadowing: and Other Techniques for Doing Fieldwork in Modern Societies, Liber and Copenhagen Business School Press, Copenhagen.

De Vries, H., Bekkers, V. and Tummers, L. (2016), "Innovation in the public sector: a systematic review and future research agenda", Public Administration, Vol. 94 No. 1, pp. 146-166.

Demircioglu, M.A. and Audretsch, D.B. (2017), "Conditions for innovation in public sector organizations”, Research Policy, Vol. 46 No. 9, pp. 1681-1691. 
Djellal, F., Gallouj, F. and Miles, I. (2013), "Two decades of research on innovation in services. Which place for public services?", Structural Change and Economic Dynamics, Vol. 27, pp. 98-117.

Duberley, J. and Cohen, L. (2010), "Gendering career capital. An investigation of scientific careers", Journal of Vocational Behavior, Vol. 76 No. 2, pp. 187-197.

Fetterman, D. (1998a), Ethnography: Step by Step, 2nd ed., Sage Publications, Thousand Oaks, CA.

Fetterman, D. (1998b), "Ethnography", in Brickman, L. and Rog, D. (Eds), Handbook of Applied Social Research Methods, Sage Publications, Thousand Oaks, CA, pp. 473-504.

Foss, L., Woll, K. and Moilanen, M. (2013), "Creativity and implementation of new ideas: do organizational structure, work environment and gender matter?", International Journal of Gender and Entrepreneurship, Vol. 5 No. 3, pp. 298-322.

Hernes, H. (1987), Welfare State and Women Power. Essays in State Feminism, Universitetsforlaget, Oslo. Irigaray, L. (1985), Speculum of the Other Woman, Cornell University Press, Ithaca, NY.

Kanter, R. (1977), Men and Women of the Corporation, Basic Books, New York.

Kvidal, T. and Ljunggren, E. (2010), "Implementing 'a gender perspective' in an innovation program: more innovation or ambivalence and uncertainty?", Paper Presented at the Conference Gender, Work and Organization, Keele University, Keele, 21-23 June, 2010.

Lincoln, Y. and Denzin, N. (2000), "The seventh moment: out of the past”, in Denzin, N.K. and Lincoln, Y.S. (Eds), Handbook of Qualitative Research, 2nd ed., Sage Publications, Thousand Oaks, CA, pp. 1047-1065.

Ljunggren, E., Alsos, G., Amble, N., Ervik, R., Kvidal, T. and Wiik, R. (2010), "Gender and innovation: learning from regional VRI-Projects”, NF-report 2/2010, Nordland Research Institute, Bodö.

Marlow, S. and McAdam, M. (2012), "Analyzing the influence of gender upon high-technology venturing within the context of business incubation", Entrepreneurship, Theory and Practice, Vol. 36 No. 4, pp. 655-676.

Marlow, S., Carter, S. and Shaw, E. (2008), "Constructing female entrepreneurship policy in the UK: is the US a relevant benchmark?", Environment and Planning C: Government and Policy, Vol. 26, pp. 335-351.

Martin, J. (1990), "Deconstructing organizational taboos: the suppression of gender conflict in organizations", Organization Science, Vol. 1 No. 4, pp. 339-357.

Martin, J. and Collinson, D. (2002), "Over the pond and across the water: developing the field of gendered organizations", Gender, Work and Organization, Vol. 9 No. 3, pp. 244-265.

Miles, I. (2005), "Innovation in Services", in Fagerberg, J., Mowery, D. and Nelson, R. (Eds), The Oxford Handbook of Innovation, Oxford University Press, Oxford.

Morgan, G. and Smircich, L. (1980), "Case of qualitative research", Academy of Management Review, Vol. 5 No. 4, pp. 491-500.

Mulgan, G. (2007), "Ready or Not? Taking innovation in the public sector seriously provocation", 3 April.

Nählinder, J. (2013), "Understanding innovation in a municipal context", Innovation: Management, Policy and Practice, Vol. 15 No. 3, pp. 315-325.

Nelson, R.K. (1969), Hunters on the Northern Ice, University of Chicago Press, Chicago.

Nyberg, A.C. (2009), "Making ideas matter: gender, technology and women's invention”, Dissertation, Department of Human Work Sciences Division of Gender and Innovation, Luleå University, Luleå.

Pecis, L. (2016), "Doing and undoing gender in innovation: femininities and masculinities in innovation processes", Human Relations, Vol. 69 No. 11, pp. 2117-2140.

Pollitt, C. and Hupe, P. (2011), "Talking about government: the role of magic concepts", Public Management Review, Vol. 13 No. 5, pp. 641-658.
Innovation practice 
IJGE 13,3

Ranga, M. and Etzkowitz, H. (2010), "Athena in the world of Techne: the gender dimension of technology, innovation and entrepreneurship", Journal of Technology Management andInnovation, Vol. 5 No. 1, pp. 1-12.

Richardson, L. (1995), "Narrative and sociology", in Van Maanen, J. (Ed.), Representations in Ethnography, Sage, Thousands Oaks, CA, pp. 198-221.

Ritala, P. and Sainio, L.M. (2014), "Coopetition for radical innovation: technology, market and businessmodel perspectives", Technology Analysis and Strategic Management, Vol. 26 No. 2, pp. 155-169.

Rosen, M. (1991), "Coming to terms with the field: understanding and doing organizational ethnography", Journal of Management Studies, Vol. 28 No. 1, pp. 1-24.

Seidl, D. and Whittington, R. (2014), "Enlarging the strategy-as-practice research agenda: towards taller and flatter ontologies", Organization Studies, Vol. 35 No. 10, p. 1407e1421, doi: 10.1177/ 0170840614541886.

Stetson, D. and Mazur, A. (Eds) (1995), Comparative State Feminism, Sage, London.

Sum, B. (1987), "The Scandinavian Welfare State - Towards Sexual Equality of a New Kind of Male Domination?”, Acta Sociologica, Vol. 30 Nos 3-4, pp. 255-269.

Thompson, N.A., Verduijn, K. and Gartner, W.B. (2020), "Entrepreneurship-as-practice: grounding contemporary theories of practice into entrepreneurship studies", Entrepreneurship and Regional Development, Vol. 32 Nos 3-4, pp. 247-256, doi: 10.1080/08985626.2019.1641978.

Van Maanen, J. (1988), Tales of the Field, The University of Chicago Press, Chicago.

Wajcman, J. (2010), "Feminist theories of technology", Cambridge Journal of Economics, Vol. 34 No. 1, pp. 143-152, doi: 10.1093/cje/ben057.

Whittington, R. (1996), “Strategy as practice”, Long Range Planning, Vol. 29 No. 5, pp. 731-735, doi: 10. 1016/0024-6301(96)00068-4.

Windrum, P. and Koch, P. (2008), Innovation in Public Sector Services, Edward Elgar, Cheltenham.

\section{Further reading}

Benington, J. and Hartley, J. (2001), "Pilots, paradigms and paradoxes: changes in public sector governance and management in the UK", International Research Symposium on Public Sector Management, Barcelona.

Hartley, J. (2005), "Innovation in governance and public services: past and present", Public Money and Management, Vol. 25 No. 1, pp. 27-34.

Nählinder, J. and Fogelberg-Eriksson, A. (2019), "Outcome, process and support: analysing aspects of innovation in public sector organizations", Public Money and Management, Vol. 39 No. 6, pp. $443-449$.

Osborne, S. (2006). "The New Public Governance", Public Management Review, Vol. 8 No. 3, pp. 377-387.

Patton, M.Q. (2002), Qualitative Research and Evaluation Methods, 3rd ed., Sage Publications, Thousand Oaks.

Spender, D. (1985), Man Made Language, 2nd ed., Routledge \& Kegan Paul, London.

\section{Corresponding author}

Caroline Wigren-Kristoferson can be contacted at: Caroline.Wigren@mau.se

For instructions on how to order reprints of this article, please visit our website:

www.emeraldgrouppublishing.com/licensing/reprints.htm

Or contact us for further details: permissions@emeraldinsight.com 